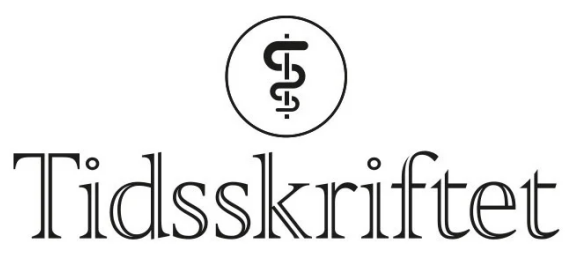

DEN NORSKE LEGEFORENING

\title{
Rettelse: Fastlegens rolle ved osteoporosebehandling etter brudd
}

\author{
RETTELSE
}

\author{
JAKOB VANGEN NORDB $\varnothing$
}

ØYVIND STOPLE SIVERTSEN

FREDE FRIHAGEN

LENE B. SOLBERG

Tidsskr Nor Legeforen 2020; 140: 1738.

I Tidsskriftet nr. 17/2020, s. 1738 skal det stå: P1 NP kan tas når som helst på døgnet på serumrør og oppbevares i kjøleskap før den sendes til analyse.

Vi beklager feilen, den er rettet på nett.

Publisert: 3. februar 2021. Tidsskr Nor Legeforen. DOI: 10.4045/tidsskr.21.0089

(C) Tidsskrift for Den norske legeforening 2023. Lastet ned fra tidsskriftet.no 26. april 2023. 